\title{
Effect of Biofertilizer on Growth and Yield Parameters of the Okra Plant ${ }^{\dagger}$
}

\author{
P. Sajeesh ${ }^{1}$, Yap Leng Leng ${ }^{1}$, P. Paulraj ${ }^{1}$, K.P. Sajna ${ }^{1}$, T. Ketharin ${ }^{1}$, P.T. Mohamed Javad ${ }^{1}$ \\ 1 School of Bioscience, Faculty of Medicine, Bioscience and Nursing, MAHSA University, Jenjarom, Selangor, Malaysia \\ * Correspondence: Not available; \\ $\dagger$ Presented at International e-Conference on Bioengineering for Health and Environment (ICBHE 2020)
}

Received: 5.07.2020; Revised: 10.07.2020; Accepted: 12.07.2020; Published: 15.07.2020

\begin{abstract}
Phosphorus is one of the plant micronutrients affecting cell division and molecular growth, such as nucleic acid, phospholipids, ATP, and so on. The presence of PSB could help turn insoluble phosphate in the soil into soluble phosphate for better growth. Potassium participates in homeostasis, osmoregulation, the function of the enzymes, etc., which can increase the quality of the plant as well as crop yield. Potassium usually appears in mineral K formed, which causes the plant could not be absorbed directly. KSB will release certain organic acid, which can help in releasing potassium ion from the soil. This study aims to compare the growth and yield between okra plants with PSB, KSB, and without PSB, KSB. PSB \& KSB were isolated from okra plants. PSB, KSB consortia, and different fertilizer (TSP, RP, OC) were prepared and applied in different okra plants. Plant parameters, total chlorophyll content, antioxidant activity, and study of phosphate solubilization were performed. A significant difference with $\mathrm{p}<0.05$ was found in RP and TSP with consortia. The highest reading was found in the plant with RP \& consortia for several leaves (14), several flowers (5.44), shoot length $(25 \mathrm{~cm})$, the mean number of fruits $(2.22)$, fruit length $(13.78 \mathrm{~cm})$, fruit weight $(25.15 \mathrm{~g})$ and antioxidant level (81.05). Thus, the presence of PSB and KSB can increase the growth and yield of the plant.
\end{abstract}

Keywords: Phosphate Solubilizing Bacteria (PSB); Potassium solubilizing bacteria (KSB) Triple Super Phosphate (TSP); Rock Phosphate (RP) Organic composts (OC); Potassium (K).

(C) 2020 by the authors. This article is an open-access article distributed under the terms and conditions of the Creative Commons Attribution (CC BY) license (https://creativecommons.org/licenses/by/4.0/).

\section{Funding}

This research received no external funding.

\section{Acknowledgments}

This research has no acknowledgment.

\section{Conflicts of Interest}

The authors declare no conflict of interest. 